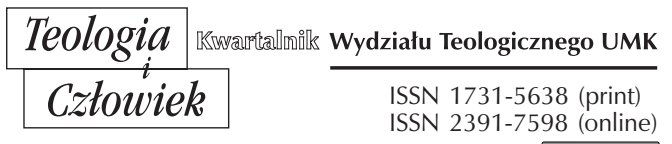

(c) (1) $\odot$

44(2018)4, ss. $57-77$

KS. DANIEL BRZEZIŃSKI

WYDZIAŁ TEOLOGICZNY UNIWERSYTETU MIKOŁAJA KOPERNIKA W TORUNIU

DANBR@OP.PL

ORCID 0000-0003-4680-3055

\title{
MSZAŁ JAKO KSIĘGA LITURGICZNA: GENEZA I EWOLUCJA
}

DOI: http://dx.doi.org/10.12775/TiCz.2018.039

Streszczenie. Bezpośrednią inspiracją niniejszego opracowania stało się wydanie monumentalnego dzieła Biskupa Toruńskiego Seniora Andrzeja Wojciecha Suskiego „Rękopiśmienne mszały przedtrydenckie. Katalog sumaryczny”. Podobnie jak wcześniejsza publikacja dotycząca sakramentarzy, dzieło to jest owocem iście benedyktyńskiej pracy przez całe ostatnie ćwierćwiecze. Sporządzone przez pierwszego Biskupa Toruńskiego przewodniki to katalogi unikatowe w nauce, stanowiące nieocenioną pomoc zwłaszcza dla badaczy historii liturgii.

W opracowaniu przedstawiono genezę i ewolucję mszału. Zanim mszał pojawił się jako jednolita księga liturgiczna przeznaczona do sprawowania Eucharystii, w celebracji Mszy św. używano wielu ksiąg: sakramentarzy, lekcjonarzy, ewangeliarzy (ewangelistarzy), graduałów i antyfonarzy, a także tekstów zawierających rubryki mszalne. Funkcjonowały one jako odrębne księgi z przeznaczeniem dla: biskupa i prezbitera (sakramentarz), subdiakona (lekcjonarz), diakona (ewangeliarz) oraz zespołu śpiewaczego (graduał). W IX wieku rozpoczyna się proces scalania owych ksiąg w jedną księgę liturgiczną, co w rezultacie spowodowało powstanie mszału pełnego (missale plenarium, missale completum), do którego wprowadzono także rubryki przejęte z przepisów określających sposób wykonania liturgii (ordines).

Słowa kluczowe: liturgia rzymska; księgi liturgiczne rzymskie; mszał rzymski.

Abstract. The Missal as a Liturgical Book: Genesis and Evolution. A direct inspiration for this study has been the publication of the monumental work The Manu- 
scripts of Pre-Tridentine Missals. A Summary Catalogue by Andrzej Wojciech Suski, Bishop Emeritus of Toruń. Like the previous publication regarding the sacramentaries, this book is the fruit of a truly Benedictine work of the last quarter of the century. The catalogues prepared by the first Bishop of Torun are the unique texts which constitute invaluable help for researchers of the history of the liturgy, in particular.

In this study we will present the genesis and evolution of the Missal. Before the Missal appeared as a uniform liturgical book intended for the celebration of the Eucharist, many books, such as sacramentaries, lectionaries, evangeliaries graduals and antiphonaries, as well as texts containing rubrics for the Mass had been used in the celebration of the Eucharist. They functioned as separate books for the bishop and the presbyter (the sacramentary), the subdeacon (the lectionary), the deacon (the evangeliary) and the singing group (gradual). In the ninth century, the process of combining these books into one liturgical text began, which resulted in the creation of a complete missal (missale plenarium, missale completum). This missal included rubrics indicating the rules which govern the celebration of the liturgy (ordines).

Key words: Roman liturgy; Roman Liturgical Books; the Roman Missal.

Bezpośrednią inspiracją niniejszego opracowania stało się wydanie monumentalnego dzieła Biskupa Toruńskiego Seniora Andrzeja Wojciecha Suskiego Rękopiśmienne mszały przedtrydenckie. Katalog sumaryczny ${ }^{1}$. Podobnie jak wcześniejsza publikacja dotycząca sakramentarzy ${ }^{2}$, dzieło to jest owocem iście benedyktyńskiej pracy przez całe ostatnie ćwierćwiecze. Sporządzone przez pierwszego Biskupa Toruńskiego przewodniki to katalogi unikatowe w nauce, stanowiące nieocenioną pomoc zwłaszcza dla badaczy historii liturgii.

W naszym opracowaniu przedstawimy genezę i ewolucję mszału³. Zanim mszał pojawił się jako jednolita księga liturgiczna przeznaczona

1 A. Suski, Rękopiśmienne mszały przedtrydenckie. Katalog sumaryczny, Toruń 2017 (=Fontes Scrutari, t. 2); zob. K. Konecki (rec.), Bp Andrzej Suski, Rękopiśmienne mszały przedtrydenckie. Katalog sumaryczny, Fontes Scrutari II, Toruń 2017, ss. 811, „Teologia i Człowiek” 40 (2017) 4, s. 297-300.

2 A. Suski, Sakramentarze. Przewodnik po rękopisach, Toruń 2016; zob. J. Stefański (rec.), Bp Andrzej Suski, Sakramentarze. Przewodnik po rękopisach, Fontes Scrutari I, Toruń 2016, ss. 1023, „Teologia i Człowiek” 36 (2016) 4, s. 253-255.

${ }^{3}$ Zob. J. Miazek, Wprowadzenie do mszałów przedtrydenckich, w: A. Suski, Rękopiśmienne mszały przedtrydenckie, s. 35-50. 
do sprawowania Eucharystii, w celebracji Mszy św. używano wielu ksiąg: sakramentarzy, lekcjonarzy, ewangeliarzy (ewangelistarzy), graduałów i antyfonarzy, a także tekstów zawierających rubryki mszalne. Funkcjonowały one jako odrębne księgi z przeznaczeniem dla: biskupa i prezbitera (sakramentarz), subdiakona (lekcjonarz), diakona (ewangeliarz) oraz zespołu śpiewaczego (graduał). W IX wieku rozpoczyna się proces scalania owych ksiąg w jedną księgę liturgiczną, co w rezultacie spowodowało powstanie mszału pełnego (missale plenarium, missale completum), do którego wprowadzono także rubryki przejęte z przepisów określających sposób wykonania liturgii (ordines).

\section{U ŹRÓDEŁ MSZAŁU}

Trudno dzisiaj dokładnie zrozumieć, a tym bardziej w miarę szczegółowo zrekonstruować proces tworzenia się najstarszych ksiąg liturgicznych. Aby poznać genezę ksiąg liturgicznych, w tym Mszału Rzymskiego, trzeba z pewnością cofnąć się aż do epoki tzw. liturgii rzymskiej czystej, czyli klasycznej, kiedy to - po nastaniu wolności Kościoła - rozwija się nie tylko budownictwo sakralne, ale też zaczyna się spisywać pierwsze formuły modlitewne.

Poprzedzający ją okres trzech pierwszych wieków chrześcijaństwa, określany w historii ksiąg liturgicznych czasem improwizacji, prawie zupełnie ginie $\mathrm{w}$ mroku naszej niewiedzy. O ewentualnie używanych wówczas w liturgii księgach - jeśli takie w ogóle istniały - praktycznie nic nie wiemy. Stąd przyjęło się uważać, że formuły euchologijne i towarzyszące im obrzędy były spontanicznie improwizowane ad hoc w lokalnej wspólnocie, a jeśli potem były również przekazywane, to w tradycji ustnej. Nie pochodziły one z jakiegoś jednego „centrum” i najprawdopodobniej nie były używane w oparciu o jeden ustalony liturgiczny „prototyp” (czy też „archetyp”), a następnie różnicowane ze względu na różny kontekst kulturowy lub celebracyjny ${ }^{4}$.

${ }^{4}$ Zob. A. Nocent, Dallimprovvisazione alla fissazione delle formule e dei riti, w: Anàmnesis. Introduzione storico-teologica alla liturgia, S. Marsili (red.), t. 2: La liturgia, panorama storico generale, Casale Monferrato 1978 (dodruk 1988), s. 131-135; I. Scicolone, Libri liturgici, w: Nuovo Dizionario di Liturgia, D. Sartore, A. M. Triacca (red.), 
Z drugiej jednak strony, trudno raczej mówić o zjawisku absolutnej spontaniczności i kreatywności w liturgii pierwszych chrześcijan, zwłaszcza w środowiskach judeochrześcijańskich. Zarówno oficjalna liturgia żydowska, jak i modlitwa prywatna w domach, choć w pewnych częściach dopuszczały swobodę i improwizację, z reguły odbywały się jednak według ściśle ustalonych schematów ${ }^{5}$.

Stąd, nie bez podstaw wydaje się założenie, że już w czasach apostolskich istniały pewne „schematy” sprawowania liturgii (przede wszystkim eucharystycznej). Mogą o tym świadczyć chociażby same nowotestamentalne przekazy ustanowienia Eucharystii (1 Kor 11,23-26; Mk 14,22-25; Mt 26,26-29; Łk 22,19-20), uznawane powszechnie (zwłaszcza fragment z Pierwszego Listu do Koryntian) za odzwierciedlenie istniejącej już w I wieku naszej ery chrześcijańskiej liturgicznej praxis „łamania chleba” (zob. Dz 2,46; 20,7-11), ściśle wzorowanej na Ostatniej Wieczerzy i wypełniającej - gdy chodzi o ipsissima verba et facta Jesu anamnetyczny nakaz Pana „To czyńcie na moją pamiątkę"6.

Z czasów bezpośrednio poapostolskich, jako świadectwo utrwalenia na piśmie modlitwy chrześcijańskiej zanoszonej nad chlebem i winem (niezależnie od wciąż trwającej dyskusji, czy chodzi o pierwowzór mo-

Cinisello Balsamo 1990, s. 701; E. Cattaneo, I Padri della Chiesa prima dei sacramentari: pastori e mistagoghi, „Rivista Liturgica” 101 (2014) 3, s. 571-578.

5 Zob. L. Ligier, Textus liturgiae Iudaeorum, w: Prex Eucharistica. Textus e variis liturgiis antiquioribus selecti, A. Hänggi, I. Pahl (red.), Fribourg 1968 (=Spicilegium Friburgense. Textus historiam vitae christianae illustrantes, t. 12), s. 4-57; S. Ben-Chorin, Betendes Judentum. Die Liturgie der Synagoge, Tübingen 1980; C. Di Sante, La preghiera di Israele. Alle origini della liturgia cristiana, Genova 1991; R. Torti Mazzi, La preghiera ebraica. Alle radici delleucologia cristiana, Cinisello Balsamo 2004.

${ }^{6}$ Zob. J. A. Jungmann, Textus Ecclesiae antiquae, w: Prex Eucharistica, s. 62-65. Wśród wielu opracowań, jakie ukazały się w języku polskim na ten temat, wskazujemy w tym miejscu: B. Nadolski, Liturgika, t. 4: Eucharystia, Poznań 2011, s. 9-16; R. Bartnicki, „To czyńcie na moja pamiątkę. Eucharystia w świetle Biblii, Warszawa 2010, s. 29-31; O. Casel, Pamiątka Pana w liturgii pierwotnego Kościoła. Główne idee kanonu mszalnego, Kraków 2000, s. 21-29; A. Läpple, Eucharystia: ustanowienie, historia, uczestnictwo, Kraków 1997, s. 11-35; W. Kasper, Jedność Eucharystii i wielość jej aspektów, w: Kolekcja „Communio”, t. 1: Eucharystia, Poznań-Warszawa 1986, zwłaszcza s. 19-27; J. Kudasiewicz, Teologia Ewangelii Synoptycznych, Lublin 1986 (=Teologia Nowego Testamentu, F. Gryglewicz (red.), t. 1), s. 9-20; K. Romaniuk, Eucharystia w przekazach biblijnych, „Ateneum Kapłańskie” 447 (1983) 2, s. 159-178. 
dlitwy eucharystycznej, czy też o dziękczynienie za pokarm wypowiadane podczas agap, wzorowane na hebrajskich berakot, w szczególności na birkat ha mazon), na uwagę zasługują 9 i 10 rozdział, pochodzącej prawdopodobnie z terenu Egiptu lub Zachodniej Syrii, a być może z Palestyny, Didachè, czyli „Nauki dwunastu Apostołów” („Nauki Pana, którą dwunastu Apostołów przekazało narodom") ${ }^{7}$.

Świadectwem nieco późniejszym, które można uznać za pierwszy „Ordo Missae”, są opisy Eucharystii zawarte w I Apologii św. Justyna (+ ok. 165), nawróconego na chrześcijaństwo filozofa i męczennika. I Apologia powstała prawdopodobnie około roku 150-153 po Chrystusie i została dedykowana cesarzowi Antoninowi Piusowi $(+161)$ oraz jego synom: Markowi Aureliuszowi $(+180)$ i Lucjuszowi Werusowi $(+169)^{8}$. Wśród celów powstania obydwu Justynowych Apologii było odparcie posądzania chrześcijan o ateizm. W kontekście tej polemiki Justyn ukazuje wyższość obrzędów chrześcijańskich nad misteriami pogańskimi. W I Apologii znajdujemy bezcenne relacje odnoszące się do przebiegu celebracji Eucharystii:

7 Wydanie krytyczne: La Doctrine des Douze Apôtres (Didachè). Introduction, texte critique, traduction, notes, appendices, annexe et augmentée, W. Rordorf, A. Tuilier (trans.), Paris 1978 (=Sources Chrétiennes, t. 248); Nauka dwunastu Apostołów (Didachè), w: Pierwsi świadkowie. Pisma Ojców Apostolskich, A. Świderkówna (tłum.), M. Starowiejski (oprac.), Kraków 1998 (=Biblioteka Ojców Kościoła, J. Naumowicz (red.), t. 10), s. 33-44; zob. J. A. Jungmann, Textus Ecclesiae antiquae, w: Prex Eucharistica, s. 66-68; P. F. Bradshaw, Alle origini del culto cristiano. Fonti e metodi per lo studio della liturgia dei primi secoli, traduzione italiana a cura delle Monache dell'Abbazia Benedettina „Mater Ecclesiae” dell'Isola San Giulio - Orta, Città del Vaticano 2007 (=Monumenta Studia Instrumenta Liturgica, M. Sodi, A. M. Triacca (red.), t. 46), s. 91-93, 138-141; E. Mazza, Lanafora eucaristica. Studi sulle origini, Roma 1992 (=Bibliotheca „Ephemerides Liturgicae”. Subsidia, C. Braga (red.), t. 62), s. 19-50. Wykaz wydań krytycznych „Didachè” oraz zestaw najważniejszych opracowań i komentarzy dotyczących tekstu podaje A. Suski, Chrzest według Didachè, w: Laudate Dominum. Księdzu profesorowi Jerzemu Stefańskiemu z okazji 65-lecia urodzin i 40-lecia kapłaństwa, K. Konecki (red.), Gniezno 2005, s. 287-306.

8 Wydanie krytyczne: Saint Justin, Apologies. Introduction, texte critique, traduction, commentaire et index, A. Wartelle (tłum.), Paris 1987; najnowsza edycja polska: Justyn, I Apologia, w: Pierwsi apologeci greccy: Kwadratus, Arystydes z Aten, Aryston z Pelli, Justyn Męczennik, Tacjan Syryjczyk, Milcjades, Apolinary z Hierapolis, Teofil z Antiochii, Hermiasz, L. Misiarczyk (tłum. i oprac.) (=Biblioteka Ojców Kościoła, J. Naumowicz (red.), t. 24), s. 207-270. 
związanej ze sprawowaniem chrztu (rozdziały 65-66) oraz Mszy świętej odprawianej w „dniu Słońca”, czyli w niedzielę (rozdział 67).

Z kolei w Traditio Apostolica („Diataxeis”) odnajdujemy anaforę, którą po Soborze Watykańskim II - po dokonaniu niezbędnych modyfikacji - w Mszale Rzymskim zamieszczono jako II Modlitwę Eucharystyczną. Wśród hipotez odnoszących się do proweniencji „Tradycji” w ubiegłym stuleciu przeważał pogląd, że mogła ona powstać w rzymskim środowisku liturgicznym, mając za autora św. Hipolita Rzymskiego $(+235)^{9}$. Dzisiaj pogląd ten jest coraz częściej podważany. Jednak w naszej refleksji nad genezą mszału, ani kwestia autorstwa, ani kwestia środowiska powstania „Traditio” nie są kluczowe. Bardziej istotne dla nas jest samo starożytne pochodzenie dzieła, które na obecnym etapie badań w najmniejszym stopniu nie jest kwestionowane, nawet jeśli uznać je za anonimową kompilację tekstów różnego pochodzenia powstałych pomiędzy wiekiem II a początkiem wieku IV ${ }^{10}$. Niestety, nie przetrwał do naszych czasów grecki tekst dzieła, za wyjątkiem odrębnie zachowanych fragmentów. $\mathrm{Na}$ podstawie istniejących przekładów, rekonstrukcji tekstu, zbliżając go na ile to możliwe do jakiegoś pierwotnego „prototypu”, dokonał B. Botte $(+1980)^{11}$. Zarówno wersja łacińska, jak i wersja etiopska „Traditio”, za-

9 Zob. P. F. Bradshaw, Alle origini del culto, s. 95-98; J. W. Boguniowski, Rozwój historyczny ksiag liturgii rzymskiej do Soboru Trydenckiego i ich recepcja w Polsce, Kraków 2001, s. 45-54.

10 Zob. B. Nadolski, Leksykon liturgii, Poznań 2006, s. 1601; B. Altaner, A. Stuiber, Patrologia. Życie, pisma i nauka Ojców Kościoła, Warszawa 1990, s. 146-148; M. Zachara, Krótka historia mszału rzymskiego, Warszawa 2014, s. 21-23.

11 Wydanie krytyczne: La Tradition apostolique de Saint Hippolyte. Essai de reconstitution, B. Botte (tłum. i oprac.), Münster 1989 (=Liturgiewissenschaftliche Quellen und Forschungen, t. 39), s. 1-103. Botte posłużył się zwłaszcza przekładem łacińskim powstałym, jak się przyjmuje, około roku 375, i zawartym w Manuskrypcie z Werony LV z końca V wieku, oraz przekładem sahidyckim Synodów Aleksandryjskich z wariantami, przy czym sam przekład z greki sporządzony został przed rokiem 700, a także wersją bohajrycką, arabską, etiopską i źródłami pochodnymi od „Traditio”. A są nimi: prawdopodobnie syryjski „Testament Pana” („Testamentum Domini”) z IV-V wieku, egipskie „Kanony Hipolita” z około 340 roku, „Konstytucje Apostolskie” z około 380 roku, syryjskie „Epitome” (czyli „Streszczenie Konstytucji Apostolskich”) z początku V wieku, „Oktateuch Klementyński” (czyli „Ośmioksiąg Klementyński”, którego grecki przekład znał już monofizycki biskup Sewer z Antiochii /+538/) oraz zapis prawodawstwa Kościoła Aleksandryjskiego z V wieku rozpowszechniony pod nazwą „Synod Aleksan- 
wierają modlitwę eucharystyczną Mszy świętej związanej ze święceniami biskupimi ${ }^{12}$. Dodajmy, że proponowana w „Traditio” modlitwa eucharystyczna dla nowo wyświęconego biskupa, który po raz pierwszy sprawuje Eucharystię jako pasterz swojego Kościoła, stanowi przykład wyraźnie ukształtowanej już euchologii, na którą składają się: dziękczynienie, anamneza oraz epikleza (jako części tejże euchologii) ${ }^{13}$.

Wśród stosunkowo licznych świadectw utrwalania modlitw i rubryk mszalnych, zanim zaczęto je spisywać dla użytku stricte liturgicznego, wypada wymienić również Konstytucje Apostolskie ${ }^{14}$. Powszechnie przyjmuje się, że dzieło to powstało w Syrii (w Antiochii?) lub w Konstantynopolu pomiędzy rokiem 375 a 380 po Chrystusie. Jest ono obszerną kompilacją wcześniejszych źródeł w języku greckim ${ }^{15}$. Składa się z ośmiu ksiąg. W Księdze VIII zawarto cały formularz mszalny (zarówno liturgię słowa, czyli tzw. „Mszę katechumenów”, jak i liturgię eucharystyczną, czyli tzw. „Mszę wiernych”) przypisywany papieżowi św. Klemensowi Rzymskiemu (+ ok. 97 po Chr.), trzeciemu następcy św. Piotra: stąd jego nazwa „Msza Klementyńska”"16.

dryjski” (inna nazwa tego dzieła to „Kanony Kościelne”); zob. B. Botte, Introduction, w: La Tradition apostolique, s. XI-XLVII; W. Niedźwiecki, Wczesnochrześcijańskie źródła kanoniczno-liturgiczne. Przewodnik bibliograficzny, Toruń 2005, s. 8-14.

12 Zob. Traditio Apostolica, rozdz. 4, w: La Tradition apostolique, s. 11-17; por. J. A. Jungmann, Textus Ecclesiae antiquae, s. 80-81. Pomijamy, jako nieistotne dla naszej prezentacji, niewielkie różnice pomiędzy tymi dwiema wersjami tekstu; tłumaczenie polskie anafory w: Eucharystia pierwszych chrześcijan. Ojcowie Kościoła nauczaja o Eucharystii, M. Starowiejski, J. Miazek, A. Luft (red.), Kraków 1997, s. 205-207.

13 Zob. E. Mazza, Lanafora eucaristica, s. 111-194.

${ }^{14}$ Wydanie krytyczne: Les Constitutions Apostoliques, 3 t., M. Metzger (tłum. i oprac.), Paris 1985-1986-1987 (=Sources Chrétiennes, t. 320. 329. 336).

15 Zob. P. F. Bradshaw, Alle origini del culto, s. 100-102.

${ }_{16}$ Zob. Constitutiones Apostolorum, księga VIII, 5, 11-15, 11, w: Les Constitutions Apostoliques, t. 3, s. 150-217; J. A. Jungmann, Textus Ecclesiae antiquae, s. 82-95; wydanie krytyczne z polskim przekładem w: Konstytucje Apostolskie oraz Kanony Pamfilosa $z$ apostolskiego synodu w Antiochii, Prawo kanoniczne świętych Apostołów, Kary świętych Apostołów dla upadłych, Euchologion Serapiona, A. Baron, H. Pietras (oprac.), Kraków 2007 (=Synody i kolekcje praw, t. 2; Źródła Myśli Teologicznej, t. 42), s. 224-250* (tłum. polskie: S. Kalinkowski); zob. D. Brzeziński, „Chrystus wczoraj i dziś, i na wieki”. Anamnetyczny wymiar roku liturgicznego, Toruń 2015, s. 147-156; tenże, Liturgia chrześcijańska celebracja Misterium Chrystusa in sacramento w świetle źródeł liturgiczno-patrystycznych, 
Na ostatnie dekady IV wieku, najpierw zwłaszcza w Afryce Północnej, przypadł początek dynamicznego rozwoju twórczości liturgicznej. Proces ten niósł jednak ze sobą ryzyko błędów doktrynalnych. W celu zapobiegania im, utrwalaniem formuł i rubryk liturgicznych poprzez tworzenie „schematów celebracyjnych” zajęły się lokalne synody (jak np. Synod w Kartaginie z roku 397, czy też Synod w Milevi z roku 416) ${ }^{17}$. Wiele formularzy mszalnych pochodzących z lat 400-450 przekazały nam starohiszpańskie liber ordinum i liber mozarabicus sacramentorum. Szczególnie aktywna w tworzeniu formuł modlitewnych była liturgia gallikańska, która - jak uważał A. Nocent (+1996) - wpłynęła w tym względzie na liturgię rzymską. Niestety, w zasadzie nie zachowały się do naszych czasów ani kompozycje rzymskie powstałe pomiędzy wiekiem III (jeśli „Traditio Apostolica” powstała w Rzymie) i pontyfikatem papieża św. Gelazego I (+496), ani te skomponowane w tamtym czasie w innych lokalnych Kościołach Półwyspu Apenińskiego ${ }^{18}$. Ciekawym wyjątkiem może tu być modlitwa eucharystyczna przytoczona przez św. Ambrożego (+397) w De sacramentis, stanowiąca istotną część późniejszego Kanonu Rzymskiego, czyli dzisiejszej I Modlitwy Eucharystycznej ${ }^{19}$.

Uzasadniona konieczność zapobiegania błędom dogmatycznym, wynikająca w dużej mierze z coraz większej masowości chrześcijaństwa jako religii w roku 313 zrównanej przez Konstantyna (+337) i Licyniusza $(+325)$ z innymi wyznaniami cesarstwa, a następnie od roku $380 \mathrm{za}$ Gracjana (+383) i Teodozjusza (+395) uznanej jako religia państwowa,

w: Quod itaque Redemptoris nostri conspicuum fuit, in sacramenta transivit. Sakramenty w Misterium Kościoła. Księga dedykowana Księdzu Profesorowi Czesławowi Krakowiakowi z okazji siedemdziesiątych urodzin, B. Migut, Z. Głowacki, W. Pałęcki (red.), Lublin 2014, s. 60-65.

17 Zob. III Synod w Kartaginie (według numeracji Collectio Hispana), kan. 21, w: Dokumenty Synodów od 381 do 431 roku, A. Baron, H. Pietras, Kraków 2010 (=Synody i kolekcje praw, t. 4; Źródła Myśli Teologicznej, t. 52), s. 77-77; Synod w Milevi, kan. 12, w: tamże, s. 231-231* (tłum. polskie: A. Caba).

18 Por. A. Nocent, Dallimprovvisazione alla fissazione, s. 132-133; L. Bouyer, Eucaristia. Teologia e spiritualità della Preghiera eucaristica, Leumann 1992 (=Collana „Liturgia e vita”, t. 3), s. 319-341.

19 Zob. Ambroży, De sacramentis, księga IV, n. 14; 21-22; 26-27, w: Ambroise de Milan, Des Sacrements. Des Mystères. Explication du Symbole, B. Botte (wyd.), Paris 1980 (=Sources Chrétiennes, t. 25 bis), s. 108-110. 114. 116. 
spowodowała stopniowe utrwalanie formuł euchologijnych na piśmie. Powstają pierwsze libelli, karty pergaminowe niejednokrotnie kopiowane także ze względów praktycznych: by dla potrzeb liturgii nie trzeba było wciąż układać nowych modlitw. Libelli, czy to jako pojedyncze karty, czy też $\mathrm{w}$ formie zbioru kart, były przekazywane $\mathrm{z}$ jednej wspólnoty do innej, służąc jako baza do tworzenia liturgii Kościołów lokalnych. Służyły również, zwłaszcza te pojedyncze, wędrownym prezbiterom. Z czasem, oprócz modlitw, zaczęto także utrwalać przebieg obrzędów liturgicznych, czyli rubryki.

Najstarszą zachowaną kolekcją owych kart pergaminowych, zawierających euchologię rzymską, pochodzącą jak się dzisiaj przyjmuje z drugiej połowy VI wieku (a więc jeszcze z okresu liturgii rzymskiej czystej, czyli klasycznej), jest tzw. Sakramentarz z Werony („tak zwany”, gdyż nie jest to sakramentarz w ścisłym tego słowa znaczeniu, ale w pewnym sensie „prywatny” zbiór modlitw mszalnych oraz modlitw dotyczących innych sakramentów i niektórych sakramentaliów; stąd bardziej odpowiednia byłaby nazwa „Zbiór liturgiczny z Werony” ${ }^{20}$. Zredagowany, jak się obecnie uważa, w pierwszej połowie VII wieku i odnaleziony w 1713 roku niekompletny (niestety) zbiór, opublikowany po raz pierwszy w roku 1735 przez G. Bianchiniego (+1764) jako księga przypisywana św. Leonowi Wielkiemu $(+461)$, przechowywany jest w Bibliotece Kapitulnej w Weronie ${ }^{21}$.

\section{KSIĘGl CZYSTE}

Od VII wieku zaczęły powstawać księgi liturgiczne zwane księgami czystymi. Każda z nich zawierała jeden rodzaj lub element celebracji

${ }^{20}$ Wydanie krytyczne: Sacramentarium Veronense, L.C. Mohlberg, L. Eizenhöfer, P. Siffrin (wyd.), Roma 1994 (=Rerum Ecclesiasticarum Documenta cura Pontificii Athenaei Sancti Anselmi de Urbe edita moderante Pontificio Instituto Liturgico, Series Maior. Fontes, t. 1).

${ }^{21}$ Zob. A. Nocent, Storia dei libri liturgici romani, w: Anàmnesis, t. 2, s. 148-149; I. Scicolone, Libri liturgici, s. 701-702; C. Folsom, I libri liturgici romani, w: Scientia liturgica. Manuale di Liturgia, A.J. Chupungco (red.), t. 1: Introduzione alla Liturgia, Casale Monferrato 1999, s. 264-266. Osobny problem badawczy stanowią zwoje liturgiczne; zob. A. W. Suski, G. Baroffio, A. Sodi, Rotoli liturgici medievali (secoli VII-XV). Censimento e bibliografia, „Rivista Liturgica” 101 (2014) 3, s. 603-621. 
i służyła jednemu celebransowi: prezbiterowi bądź biskupowi. Wśród rzymskich ksiąg czystych wyodrębnić można kilka zasadniczych. Są nimi: sakramentarze, lekcjonarze, antyfonarze oraz tzw. ordines romani ${ }^{22}$.

Sakramentarze to księgi służące biskupowi bądź prezbiterowi do sprawowania liturgii sakramentów świętych i sakramentaliów (w związku z rozwojem tych ostatnich, a zwłaszcza błogosławieństw biskupich, z sakramentarzy wyodrębniły się tzw. benedykcjonały ${ }^{23}$ ).

Najstarszym, znanym nam sakramentarzem jest tzw. Sakramentarz Gelazjański. Przechowywany obecnie w Apostolskiej Bibliotece Watykańskiej jedyny manuskrypt sakramentarza zwanego Gelasianum Vetus (Liber sacramentorum Romanae Ecclesiae ordinis anni circuli; Reginensis latinus 316) powstał prawdopodobnie około 750 roku w klasztorze w Chelles koło Paryża lub w klasztorze w Saint-Denis ${ }^{24}$. Zachowany rękopis, w którym już wyraźnie widać wpływy gallikańskie na euchologię rzymską, jest najprawdopodobniej kopią wcześniej istniejącej księgi, być może sięgającej czasów papieża Gelazego, a więc końca V wieku. A. Chavasse $(+2005)$ uznał Gelasianum Vetus za księgę powstałą dla prezbiterów rzymskich z kościołów tytularnych Wiecznego Miasta i opowiadał się za Rzymem jako miejscem powstania prototypu księgi; natomiast K. Gamber (+1989) - za Rawenną. Gelasianum Vetus stał się podstawą dla pochodzących z VIII stulecia sakramentarzy obecnie zwanych Gelasiana młodsze, a niegdyś - Missalia regis Pipini ${ }^{25}$.

Z kolei tzw. Sakramentarz Gregoriański, łączony z osobą papieża św. Grzegorza I Wielkiego (+604), a właściwie całą „rodzinę gregoriańską" sakramentarzy możemy poznać za pośrednictwem wielu rękopisów posiadających wspólny tytuł: „Incipit liber sacramentorum de circuli anni expositus a S. Gregorio papa romano editus". Sakramentarz Gregoriański

22 Zob. I. Scicolone, Libri liturgici, s. 702-704.

${ }_{23}$ Zob. J. W. Boguniowski, Rozwój historyczny ksiąg liturgii rzymskiej, s. 83-89.

${ }^{24}$ Wydanie krytyczne: Liber Sacramentorum Romanae Aeclesiae ordinis anni circuli, L.C. Mohlberg (wyd.), Romae 1981 (=Rerum Ecclesiasticarum Documenta, Series Maior. Fontes, t. 4).

${ }^{25}$ Zob. A. Nocent, Storia dei libri liturgici romani, s. 150-152. 156; C. Folsom, I libri liturgici romani, s. 267-270; J. W. Boguniowski, Rozwój historyczny ksiąg liturgii rzymskiej, s. 72-77; L. Michelini Tocci, Il manoscritto del Sacramentario Gelasiano, „Rivista Liturgica” 101 (2014) 3, s. 477-500. 
powstał dla potrzeb liturgii papieskiej, w tym rzymskiej liturgii stacyjnej, co odróżnia go wyraźnie od Sakramentarza Gelazjańskiego. Wśród zachowanych manuskryptów Gregorianum można wyodrębnić dwa główne typy księgi: Sakramentarz Hadriański $i^{26}$ oraz Sakramentarz Padewski ${ }^{27}$.

Pierwszy z nich to księga przekazana jako kodeks z czasów Grzegorza Wielkiego królowi Franków Karolowi Wielkiemu (+814) przez papieża Hadriana I (+795) i zdeponowana w Akwizgranie; księga wielokrotnie potem przepisywana z zaznaczeniem: „Ex authentico libro bibliothecae cubiculi”. Obecnie przyjmuje się, że najwierniejszą kopią Sakramentarza Hadriańskiego jest manuskrypt przechowywany w Bibliotece Miejskiej w Cambrai. Ponieważ sakramentarz, jaki otrzymał Karol Wielki, był pomyślany dla liturgii papieskiej, brakowało w nim wielu formularzy niezbędnych dla Kościołów lokalnych. Ułożono więc dodatek do księgi (rozpoczynający się od słowa „Hucusque”), w dużej mierze bazujący na Gelasianum z VIII wieku i zawierający wiele frankońskich (a także hiszpańskich) lokalnych zwyczajów liturgicznych. Za autora owego „Suplementu” niegdyś uważano Alkuina $(+804)$, nauczyciela i doradcę Karola Wielkiego. Obecnie autorstwo to przypisuje się opatowi benedyktyńskiemu, św. Benedyktowi z Aniane (+821).

Drugi typ Sakramentarza Gregoriańskiego stanowi rękopis przechowywany w Bibliotece Kapitulnej w Padwie. Składa się on z dwóch części: właściwego sakramentarza (zredagowanego w okolicach Liège nad Mozą około połowy IX wieku) oraz różnych dodatków pochodzących z okresu od połowy IX wieku do wieku XI. Uczeni, którzy zajmowali się księgą, wyrażali bardzo podzielone opinie co do chronologicznej i treściowej zależności Sakramentarza Padewskiego od Sakramentarza Hadriańskiego ${ }^{28}$.

${ }^{26}$ Wydanie krytyczne: Le Sacramentaire Grégorien. Ses principales formes d'aprés les plus anciens manuscrits, wyd. J. Deshusses: t. 1 (Le Sacramentaire, Le Supplément d’Aniane), Fribourg 1979 (=Spicilegium Friburgense, t. 16); t. 2 (Textes complémentaires pour la Messe), Fribourg 1979 (=Spicilegium Friburgense, t. 24); t. 3 (Textes complémentaires divers), Fribourg 1982 (=Spicilegium Friburgense, t. 28).

27 Wydanie krytyczne: Liber Sacramentorum Paduensis, wyd. A. Catella, F. Dell'Oro, A. Martini, Roma 2005 (=Bibliotheca „Ephemerides liturgicae”. Subsidia, t. 131; Monumenta Italiae Liturgica, t. 3).

${ }_{28}$ Zob. A. Nocent, Storia dei libri liturgici romani, s. 152-156; C. Folsom, I libri liturgici romani, s. 270-273. 
Zanim powstały lekcjonarze, czyli księgi zawierające czytania biblijne z przeznaczeniem do wykorzystania ich w liturgii, czytania wykonywano wprost $\mathrm{z}$ Biblii jako lectio continua bądź semicontinua. $\mathrm{Z}$ czasem odpowiednie perykopy zaczęto zaznaczać $\mathrm{w}$ kodeksach Biblii na marginesie tekstu. Następnym etapem było sporządzanie wykazów czytań poprzez określanie perykop na poszczególne dni liturgiczne za pomocą pierwszego i ostatniego słowa danego fragmentu Pisma Świętego. Stąd wzięła się nazwa capitularia. W czasach, kiedy księgi Pisma Świętego nie były jeszcze podzielone na rozdziały, a te na wersety, czyli co najmniej do XIII wieku, był to jedyny sposób umożliwiający posługiwanie się Pismem Świętym w praktyce liturgicznej zgodnie z zaplanowanym układem czytań. Stopniowe opracowywanie katalogów tekstów biblijnych pozwoliło na ostatecznie uformowanie lekcjonarza (w pełnym tego słowa znaczeniu, tzn. z pełnymi tekstami Pisma Świętego) jako księgi czystej. W ewangeliarzu (ewangelistarzu) zamieszczano fragmenty Ewangelii, zaś w epistolarzu (zwanym też Apostolus ze względu na Listy Apostolskie) inne perykopy Pisma Świętego.

Wśród wykazów perykop epistoł możemy wyróżnić trzy typy odnośnych katalogów. Reprezentantem pierwszego typu jest Comes z Würzburga (przy czym comes, albo liber comitis, bądź liber commicus, może zawierać również wykazy fragmentów Ewangelii), pochodzący z VIII wieku, używany w Rzymie, a będący świadkiem liturgii wieków VI oraz VII, czyli epoki Gelasianum Vetus ${ }^{29}$. Drugi typ reprezentuje tzw. Comes Alkuina, ułożony za pontyfikatu papieża Honoriusza I (+638). W księdze, przy redakcji której wykorzystano Comes z Würzburga, widać strukturę gregoriańską. Comes Alcuini za czasów Karola Wielkiego przywieziono do Francji, gdzie otrzymał suplement, w którym wymienia się imię Alkuina. Trzeci typ epistolarza stanowi grupa licznych rękopisów (nie wszystkie są jeszcze w pełni zidentyfikowane) dających się podzielić na dwie rodziny. Manuskrypty należące do pierwszej z nich powstały w Rzymie około roku 900; a księgi należące do drugiej to - zredagowane na terenach frankońskich - adaptacje owych rzymskich epistolarzy dostosowane do

29 Zob. Le plus ancien comes ou lectionnaire de l'Église romaine, oprac. G. Morin, „Revue bénédictine” 27 (1910), s. 41-74; Lévangéliaire de Wurtzbourg, oprac. G. Morin, „Revue bénédictine” 28 (1911), s. 296-330. 
sakramentarzy gelazjańskich młodszych. Do rzymsko-gallikańskiej grupy epistolarzy zalicza się Comes z Murbach ${ }^{30}$ oraz Comes z Corbie (obecnie przechowywany w Petersburgu). Warto dodać, że na terenie Italii już na przełomie VII i VIII wieku powstawały epistolarze z tekstami czytań w całości ${ }^{31}$.

Natomiast gdy chodzi o ewangeliarze, to da się je zgrupować - jak uczynił to T. Klauser (+1984), który przeanalizował około tysiąca odnośnych rękopisów - w czterech rodzinach. Trzy z nich ( $\Pi, \Lambda$, $\Sigma$, odpowiednio z lat: 645,740 oraz 755$)$ określane są jako rzymskie, a czwarta jako rzymsko-gallikańska ( $\Delta, \mathrm{z}$ roku 750 ), zależna od pierwszej z rzymskich rodzin. Nieco innej klasyfikacji dokonał A. Chavasse. Według niego pierwszy typ ewangeliarzy reprezentuje rodzina gallikańska. Typ drugi (czysty rzymski) to rodzina gregoriańska (odpowiadająca rodzinie $\Pi$, reprezentowanej przez Capitulare evangeliorum z Würzburga; w VIII wieku Capitulare evangeliorum $\mathrm{z}$ Würzburga dałby początek dwom rodzinom: $\Lambda$ i $\Sigma$ ). Typ trzeci, zaś, to kodeksy powstałe w Rzymie około roku 700 oraz kodeksy zredagowane w Państwie Franków około połowy VIII wieku, a więc księgi typu drugiego z suplementami ${ }^{32}$.

Opisując genezę mszału jako księgi liturgicznej, wypada wspomnieć także o antyfonarzu mszalnym, czyli księdze zawierającej antyfony przeznaczone do śpiewu podczas Mszy świętej; księdze zwanej w starożytności antiphonarius, antiphonale lub liber antiphonarius (w Rzymie - cantatorium, w krajach frankońskich - graduale). O istnieniu tego typu księgi liturgicznej zaświadczają między innymi rozporządzenia starożytnych synodów, jak również rubryki zawarte w Odo Romanus $I^{33}$. Najstarsze z zachowanych antyfonarzy pochodzą VIII i IX wieku. Z reguły nie po-

30 Zob. Le comes de Murbach, oprac. A. Wilmart, „Revue bénédictine” 30 (1913), s. $25-69$.

${ }^{31}$ Zob. J. W. Boguniowski, Rozwój historyczny ksiąg liturgii rzymskiej, s. 94-95.

32 Zob. A. Nocent, Storia dei libri liturgici romani, s. 157-161; C. Folsom, I libri liturgici romani, s. 274-278; J. W. Boguniowski, Rozwój historyczny ksiag liturgii rzymskiej, s. 89-95. 102-103. 107-111; N. Valli, I lezionari al tempo dei sacramentari Veronese, Gelasiano e Gregoriano, „Rivista Liturgica” 101 (2014) 3, s. 501-521.

${ }^{33}$ Por. Ordo Romanus I, 57, w: Les Ordines Romani du haut Moyen Age, t. 2: Les Textes (Ordines I-XIII), wyd. M. Andrieu, Louvain 1948 (=Spicilegium Sacrum Lovaniense, t. 23), s. 86. 
siadają one notacji muzycznej, czyli neum, które pojawiają się począwszy od X stulecia ${ }^{34}$.

$\mathrm{Z}$ kolei ordines to księgi zawierające liturgiczno-prawne dyspozycje odnoszące się do celebracji, czyli rubryki niezbędne w sprawowaniu Eucharystii, obok modlitw (zawartych w sakramentarzach), czytań biblijnych (zawartych w lekcjonarzach i ewangeliarzach) oraz antyfon (zawartych $\mathrm{w}$ antyfonarzach). Tak więc, ordo bądź ordinarium to opis przebiegu wykonywanych czynności liturgicznych, przy czym termin ordinarium na określenie księgi pojawia się począwszy od XI wieku, zanika w wieku XV, i dotyczy głównie norm i zwyczajów liturgicznych Kościołów partykularnych lub klasztorów. W przypadku zakonów i klasztorów używano także nazwy consuetidines monasticae, a dla diecezji - capitularia. Pewnym rodzajem ordo rzymskiego byłby również tzw. liber diurnus z wieków VII i VIII, w którym podano ryty i modlitwy związane z konsekracją papieża, czy też biskupów Kościołów podrzymskich. Zachowane i odnalezione Ordines Romani (najstarsze sięgają VII stulecia) doczekały się począwszy od XVI wieku kilku wydań. Autorem ostatniego z nich jest M. Andrieu (+1956), który po przeanalizowaniu bardzo wielu manuskryptów i wyodrębnieniu dwóch rodzin rękopisów (czystej rzymskiej i rzymskiej zaadaptowanej dla terenów dzisiejszej Francji i Niemiec), opublikował 50 ordines, dzieląc je na 10 sekcji tematycznych ${ }^{35}$.

${ }^{34}$ Synoptyczna edycja sześciu najstarszych zachowanych antyfonarzy: Antiphonale Missarum sextuplex, wyd. R. J. Hesbert, Roma 1967; zob. A. Nocent, Storia dei libri liturgici romani, s. 161-163; C. Folsom, I libri liturgici romani, s. 278-282; J. W. Boguniowski, Rozwój historyczny ksiag liturgii rzymskiej, s. 121-126; G. Baroffio, I libri per il canto: una pluralità di generi per una diversità di ministeri, „Rivista Liturgica” 101 (2014) 3, s. 523-546.

35 Wydanie krytyczne: Les Ordines Romani du haut Moyen Age, 5 t., wyd. M. Andrieu, Louvain 1931-1961 (=Spicilegium Sacrum Lovaniense. Études et Documents, t. 11. 23. 24. 28. 29); zob. A. Nocent, Storia dei libri liturgici romani, s. 163-165; C. Folsom, I libri liturgici romani, s. 316-322; J. W. Boguniowski, Rozwój historyczny ksiag liturgii rzymskiej, s. 143-155; P. Sorci, Gli Ordines Romani e la celebrazione dell'Eucaristia, degli altri sacramenti e sacramentali, „Rivista Liturgica” 101 (2014) 3, s. 547-570. 


\section{OD SAKRAMENTARZA DO MSZAŁU PEŁNEGO}

Wśród wymienionych tzw. ksiąg czystych, niejako pierwszą formą mszału i jego „prototypem” były sakramentarze, w których zawarto część obrzędów sakramentalnych odnoszącą się do celebransa. Pod koniec X wieku zaczynają pojawiać się sakramentarze, w których obok euchologii znajdują się lektury biblijne i śpiewy. W ten sposób powstają pierwsze mszały w pełnym tego słowa znaczeniu: księgi pełne, czyli wystarczające do sprawowania Mszy świętej bez konieczności posługiwania się innymi księgami, zwane liber missalis, missale bądź missale plenarium. W wyniku połączenia tekstów modlitw z tekstami Pisma Świętego przeznaczonymi na Eucharystię danego dnia, z antyfonami oraz z rubrykami mszalnymi, powstaje księga zawierająca wszystkie elementy liturgii eucharystycznej. Na skutek tego procesu, w wieku XII do rzadkości należą już dawne sakramentarze, które w kolejnym stuleciu niemalże zupełnie przestaną istniećs ${ }^{36}$.

Około roku 1000 dokonuje się więc swoisty przełom w liturgii zachodniej: powstają księgi pełne, zwane też mieszanymi, które zastąpią dotychczasowe tzw. księgi czyste ${ }^{37}$. Oprócz mszału, w ten sposób „narodzą się": pontyfikał (księga przeznaczona dla biskupa) ${ }^{38}$, rytuał (księga dla prezbitera zwana również: agenda, liber agendorum, ordinarium, manuale, albo sacerdotale) ${ }^{39}$ oraz brewiarz („skrócona” księga dla duchownych nie mogących brać udziału w chórowej celebracji Officium Divinum, zawierająca elementy zaczerpnięte z: psałterza, homiliarza, księgi lektur biblijnych, patrystycznych i hagiograficznych, hymnarza, antyfonarza oraz

${ }^{36}$ Zob. A. Nocent, Storia dei libri liturgici romani, s. 169; J. W. Boguniowski, Rozwój historyczny ksiąg liturgii rzymskiej, s. 182-194.

37 Zob. I. Scicolone, Libri liturgici, s. 704-706.

${ }^{38}$ Najbardziej znane z pierwszych pontyfikałów to: Pontificale Romano-Germanicum saeculi X, Pontificale Romanum saeculi XII, Pontificale secundum consuetudinem et usum Curiae Romanae (z XIII wieku), Pontificale Gulielmi Durandi (z XIII wieku); zob. A. Nocent, Storia dei libri liturgici romani, s. 165-168; C. Folsom, I libri liturgici romani, s. 322-327; J. W. Boguniowski, Rozwój historyczny ksiąg liturgii rzymskiej, s. 159-170.

39 Zob. A. Nocent, Storia dei libri liturgici romani, s. 169-170; C. Folsom, I libri liturgici romani, s. 327-330; J. W. Boguniowski, Rozwój historyczny ksiąg liturgii rzymskiej, s. $218-229$. 
orationale, zwanego też kolektarzem; za jej pierwotną wersję można uznać mszał scalony z brewiarzem $)^{40}$.

Przyczyn takiej kompilacji ksiąg należy upatrywać w liturgicznej i pastoralnej praktyce średniowiecznego Kościoła. O ile w kościołach katedralnych i w dużych klasztorach ksiąg potrzebnych do sprawowania liturgii (chociaż bardzo kosztownych i cennych) z pewnością nie brakowało, o tyle inne kościoły (których wciąż przybywało w dynamicznie rozwijającej się wówczas na Zachodzie Europy sieci parafii) na co najmniej kilka takich ksiąg pozwolić sobie nie mogły. Ze względu na rozwój osadnictwa, a co za tym idzie powstawanie wspólnot parafialnych, jak i misje ludowe prowadzone w kolejnych stuleciach przez nowo powstałe zakony, tworzy się jedną księgę, która będzie wystarczać do sprawowania Mszy świętej.

Wydaje się jednak, że głównym powodem powstania mszału było wprowadzanie począwszy od VI wieku tzw. Mszy prywatnych (czyli sprawowanych bez udziału ludu), co z kolei pociągnęło za sobą praktykę tzw. święceń absolutnych, czyli święceń prezbiteratu udzielanych nie ze względu na konkretną wspólnotę wiernych i posługę duszpasterską wobec nich. Zjawisko Missa privata spowodowało istotne zmiany w sprawowaniu Eucharystii. Dla licznych celebracji prywatnych potrzeba było wielu ołtarzy i wielu prezbiterów, ale nie lektorów, kantorów i psałterzystów. Kapłani altarzyści (głównie zakonni), święceni jedynie dla sprawowania Mszy świętych, zastąpili wykonujących różne posługi w mszalnym zgromadzeniu liturgicznym. Otrzymali księgę, z której łatwo korzystać jednej osobie, gdyż zawarto w niej wszystkie elementy celebracji eucharystycznej ${ }^{41}$.

Mszał powstaje w momencie, gdy rozpowszechniony jest już $\mathrm{Sa}$ kramentarz Gregoriański Hadriański ze swoim gallikańskim suplementem. Mszał w zasadzie tę księgę powiela, uwzględniając wszakże potrzeby

${ }^{40}$ Najbardziej rozpowszechniony średniowieczny brewiarz, stanowiący podstawę dla potrydenckiego Breviarium Romanum, to tzw. Breviarium secundum consuetudinem Romanae Curiae (Romanae Ecclesiae) z początku XIII wieku; zob. A. Nocent, Storia dei libri liturgici romani, s. 172-176; C. Folsom, I libri liturgici romani, s. 290-316; J. W. Boguniowski, Rozwój historyczny ksiąg liturgii rzymskiej, s. 203-217.

${ }^{41}$ Por. A. Nocent, Storia dei libri liturgici romani, s. 169; B. Nadolski, Święcenia absolutne i święcenia zakonników, w: Studia liturgiczne, t. 7: Prezbiterzy w Kościele do Soboru Trydenckiego. Liturgia święceń, teologia, ministerium, red. C. Krakowiak, W. Pałęcki, Lublin 2011, s. 71-84; M. Zachara, Krótka historia, s. 90-92. 
Kościołów lokalnych. W procesie prowadzącym do powstania mszału pełnego zaznaczają się dwa systemy: 1) zestawianie obok siebie wcześniej odrębnych ksiąg: sakramentarz - graduał, sakramentarz - lekcjonarz itp., co dało w rezultacie mszał złożony (missale compositum); 2) pełne scalenie w każdym formularzu mszalnym elementów przejętych z wcześniejszych ksiąg (oracje, czytania i teksty do śpiewu), które następują po sobie według ordo missae. Wprawdzie obydwa systemy funkcjonowały równolegle $\mathrm{w}$ czasie, to jednak drugi bardziej się upowszechnił z racji praktycznych. Znaczący wpływ miały tu libelli missarum, zawierające w poszczególnych formularzach mszalnych modlitwy, czytania i teksty do śpiewu. Służyły one jako formularze dla nowych obchodów liturgicznych. Z kolei formularze mszy wotywnych były użyteczne dla kapłanów podróżujących (missae itinerantium).

Pod koniec XIII stulecia, głównie za sprawą Zakonu Franciszkańskiego, zostaje rozpowszechniony tzw. Missale secundum consuetudinem Romanae Curiae, księga opracowana dla liturgii papieskiej. Zdominuje ona inne tego typu księgi. Jej znaczenie w liturgii Kościoła Zachodniego wzrośnie jeszcze bardziej, gdy właśnie ten mszał z nieznacznymi zmianami zostanie wydrukowany w Mediolanie, w roku 1474, jako editio princeps ${ }^{42}$, stając się następnie podstawą dla potrydenckiego Missale Romanum św. Piusa V $(+1572)^{43}$, promulgowanego w roku 1570 i obowiązującego w Kościele Zachodnim przez kolejne 400 lat, aż do ogłoszenia w 1970 roku pierwszej edycji Mszału Rzymskiego św. Pawła VI $(+1978)^{44}$.

${ }^{42}$ Zob. Missalis Romani editio princeps: Mediolani anno 1474 prelis mandata, wyd. C. Johnson, A. Ward (=Bibliotheca „Ephemerides liturgicae”. Subsidia; Instrumenta Liturgica Quarreriensia. Supplementa, t. 3), Roma 1996.

${ }^{43}$ Missale Romanum. Editio princeps (1570), edizione anastatica, introduzione e appendice, wyd. M. Sodi, A. M. Triacca, Città del Vaticano 1998 (=Monumenta Liturgica Concilii Tridentini, t. 2).

${ }^{44}$ Zob. A. Nocent, Storia dei libri liturgici romani, s. 177-179. Ogólną charakterystykę mszałów w epoce przedtrydenckiej, również w kontekście historycznym, przedstawia M. Zachara, Krótka historia, s. 95-109. 


\section{BIBLIOGRAFIA}

Altaner B., Stuiber A., Patrologia. Życie, pisma i nauka Ojców Kościoła, Warszawa 1990. Ambroise de Milan, Des Sacrements. Des Mystères. Explication du Symbole, wyd. B. Botte, wyd. drugie, Paris 1980 (=Sources Chrétiennes, t. 25 bis).

Antiphonale Missarum sextuplex, wyd. R. J. Hesbert, Roma 1967.

Baroffio G., I libri per il canto: una pluralità di generi per una diversità di ministeri, „Rivista Liturgica” 101 (2014) 3, s. 523-546.

Bartnicki R., „To czyńcie na moja pamiątkę”. Eucharystia w świetle Biblii, Warszawa 2010. Ben-Chorin S., Betendes Judentum. Die Liturgie der Synagoge, Tübingen 1980.

Boguniowski J.W., Rozwój historyczny ksiagg liturgii rzymskiej do Soboru Trydenckiego i ich recepcja $w$ Polsce, Kraków 2001.

Bouyer L., Eucaristia. Teologia e spiritualità della Preghiera eucaristica, wyd. drugie, Leumann 1992 (=Collana „Liturgia e vita”, t. 3), s. 319-341.

Bradshaw P.F., Alle origini del culto cristiano. Fonti e metodi per lo studio della liturgia dei primi secoli, traduzione italiana a cura delle Monache dell'Abbazia Benedettina „Mater Ecclesiae” dell'Isola San Giulio - Orta, Città del Vaticano 2007 (=Monumenta Studia Instrumenta Liturgica, red. M. Sodi, A. M. Triacca, t. 46).

Brzeziński D., „Chrystus wczoraj i dziś, i na wieki”. Anamnetyczny wymiar roku liturgicznego, Toruń 2015.

Brzeziński D., Liturgia chrześcijańska celebracja Misterium Chrystusa in sacramento w świetle źródeł liturgiczno-patrystycznych, w: B. Migut, Z. Głowacki, W. Pałęcki (red.), Quod itaque Redemptoris nostri conspicuum fuit, in sacramenta transivit. Sakramenty w Misterium Kościoła. Księga dedykowana Księdzu Profesorowi Czesławowi Krakowiakowi z okazji siedemdziesiątych urodzin, Lublin 2014, s. 60-65.

Casel O., Pamiątka Pana w liturgii pierwotnego Kościoła. Główne idee kanonu mszalnego, Kraków 2000 (=Modlitwa Kościoła, t. 1).

Cattaneo E., I Padri della Chiesa prima dei sacramentari: pastori e mistagoghi, „Rivista Liturgica” 101 (2014) 3, s. 571-587.

Di Sante C., La preghiera di Israele. Alle origini della liturgia cristiana, wyd. drugie, Genova 1991.

Dokumenty Synodów od 381 do 431 roku, oprac. A. Baron, H. Pietras, Kraków 2010 (=Synody i kolekcje praw, t. 4; Źródła Myśli Teologicznej, t. 52).

Eucharystia pierwszych chrześcijan. Ojcowie Kościoła nauczają o Eucharystii, oprac. M. Starowiejski, J. Miazek, A. Luft, Kraków 1997.

Folsom C., I libri liturgici romani, w: Scientia liturgica. Manuale di Liturgia, red. A. J. Chupungco, t. 1: Introduzione alla Liturgia, wyd. drugie, Casale Monferrato 1999, s. 263-330.

Jungmann J.A.(opr.), Textus Ecclesiae antiquae, w: Prex Eucharistica. Textus e variis liturgiis antiquioribus selecti, red. A. Hänggi, I. Pahl, Fribourg 1968 (=Spicilegium Friburgense. Textus historiam vitae christianae illustrantes, t. 12), s. 59-95. 
Kasper W., Jedność Eucharystii i wielość jej aspektów, w: Kolekcja „Communio”, t. 1: Eucharystia, Poznań-Warszawa 1986, s. 19-40.

Konecki K. (rec.), Bp Andrzej Suski, Rękopiśmienne mszały przedtrydenckie. Katalog sumaryczny, Fontes Scrutari II, Wyd. A. Marszałek, Toruń 2017, ss. 811, „Teologia i Człowiek" 40 (2017) 4, s. 297-300.

Kudasiewicz J., Teologia Ewangelii Synoptycznych, Lublin 1986 (=Teologia Nowego Testamentu, red. F. Gryglewicz, t. 1).

La Doctrine des Douze Apôtres (Didachè). Introduction, texte critique, traduction, notes, appendices, annexe et augmentée, tłum. i oprac. W. Rordorf, A. Tuilier, Paris 1978 (=Sources Chrétiennes, t. 248).

La Tradition apostolique de Saint Hippolyte. Essai de reconstitution, tłum. i oprac. B. Botte, Münster 1989 (=Liturgiewissenschaftliche Quellen und Forschungen, t. 39), s. 1-103.

Läpple A., Eucharystia: ustanowienie, historia, uczestnictwo, Kraków 1997.

Le comes de Murbach, oprac. A. Wilmart, „Revue bénédictine” 30 (1913), s. 25-69.

L’évangéliaire de Wurtzbourg, oprac. G. Morin, „Revue bénédictine” 28 (1911), s. 296-330.

Le plus ancien comes ou lectionnaire de l'Église romaine, oprac. G. Morin, „Revue bénédictine" 27 (1910), s. 41-74.

Le Sacramentaire Grégorien. Ses principales formes d'aprés les plus anciens manuscrits, wyd. J. Deshusses: t. 1 (Le Sacramentaire, Le Supplément d'Aniane), Fribourg 1979 (=Spicilegium Friburgense, t. 16); t. 2 (Textes complémentaires pour la Messe), Fribourg 1979 (=Spicilegium Friburgense, t. 24); t. 3 (Textes complémentaires divers), Fribourg 1982 (=Spicilegium Friburgense, t. 28).

Les Constitutions Apostoliques, 3 t., tłum. i oprac. M. Metzger, Paris 1985-1986-1987 (=Sources Chrétiennes, t. 320. 329. 336).

Les Ordines Romani du haut Moyen Age, 5 t., wyd. M. Andrieu, Louvain 1931-1961 (=Spicilegium Sacrum Lovaniense. Études et Documents, t. 11. 23. 24. 28. 29).

Liber Sacramentorum Paduensis, wyd. A. Catella, F. Dell'Oro, A. Martini, Roma 2005 (=Bibliotheca „Ephemerides liturgicae”. Subsidia, t. 131; Monumenta Italiae Liturgica, t. 3).

Liber Sacramentorum Romanae Aeclesiae ordinis anni circuli, wyd. L. C. Mohlberg, Romae 1981 (=Rerum Ecclesiasticarum Documenta, Series Maior. Fontes, t. 4).

Ligier L. (opr.), Textus liturgiae Iudaeorum, w: Prex Eucharistica. Textus e variis liturgiis antiquioribus selecti, red. A. Hänggi, I. Pahl, Fribourg 1968 (=Spicilegium Friburgense. Textus historiam vitae christianae illustrantes, t. 12), s. 1-57.

Mazza E., L'anafora eucaristica. Studi sulle origini, Roma 1992 (=Bibliotheca „Ephemerides Liturgicae". Subsidia, red. C. Braga, t. 62).

Miazek J., Wprowadzenie do mszałów przedtrydenckich, w: Rękopiśmienne mszały przedtrydenckie. Katalog sumaryczny, Torun 2017 (=Fontes Scrutari, t. 2), s. 35-50.

Michelini Tocci L., Il manoscritto del Sacramentario Gelasiano, „Rivista Liturgica” 101 (2014) 3, s. 477-500.

Missale Romanum. Editio princeps (1570), edizione anastatica, introduzione e appendice, 
wyd. M. Sodi, A. M. Triacca., Città del Vaticano 1998 (=Monumenta Liturgica Concilii Tridentini, t. 2).

Missalis Romani editio princeps: Mediolani anno 1474 prelis mandata, wyd. C. Johnson, A. Ward (=Bibliotheca „Ephemerides liturgicae”. Subsidia; Instrumenta Liturgica Quarreriensia. Supplementa, t. 3), Roma 1996.

Nadolski B., Leksykon liturgii, Poznań 2006.

Nadolski B., Liturgika, t. 4: Eucharystia, wyd. drugie uzupełnione, Poznań 2011.

Nadolski B., Święcenia absolutne i święcenia zakonników, w: Studia liturgiczne, t. 7: Prezbiterzy w Kościele do Soboru Trydenckiego. Liturgia święceń, teologia, ministerium, red. C. Krakowiak, W. Pałęcki, Lublin 2011, s. 71-84.

Niedźwiecki W., Wczesnochrześcijańskie źródła kanoniczno-liturgiczne. Przewodnik bibliograficzny, Toruń 2005.

Nocent A., Dall'improvvisazione alla fissazione delle formule e dei riti, w: Anàmnesis. Introduzione storico-teologica alla liturgia, red. S. Marsili, t. 2: La liturgia, panorama storico generale, Casale Monferrato 1978 (dodruk 1988), s. 131-135.

Nocent A., Storia dei libri liturgici romani, w: Anàmnesis. Introduzione storico-teologica alla liturgia, red. S. Marsili, t. 2: La liturgia, panorama storico generale, Casale Monferrato 1978 (dodruk 1988), s. 147-183.

Romaniuk K., Eucharystia w przekazach biblijnych, „Ateneum Kapłańskie” 447(1983) 2, s. $159-178$.

Sacramentarium Veronense, wyd. L.C. Mohlberg, L. Eizenhöfer, P. Siffrin, Roma 1994 (=Rerum Ecclesiasticarum Documenta cura Pontificii Athenaei Sancti Anselmi de Urbe edita moderante Pontificio Instituto Liturgico, Series Maior. Fontes, t. 1).

Saint Justin, Apologies. Introduction, texte critique, traduction, commentaire et index, tłum. i oprac. A. Wartelle, Paris 1987.

Scicolone I., Libri liturgici, w: Nuovo Dizionario di Liturgia, red. D. Sartore, A. M. Triacca, wyd. czwarte, Cinisello Balsamo 1990, s. 701-713.

Sorci P., Gli Ordines Romani e la celebrazione dell'Eucaristia, degli altri sacramenti e sacramentali, „Rivista Liturgica” 101 (2014) 3, s. 547-570.

Stefański J. (rec.), Bp Andrzej Suski, Sakramentarze. Przewodnik po rękopisach. Fontes Scrutari I, Toruń 2016, ss. 1023, „Teologia i Człowiek” 36 (2016). 4, s. 253-255 .

Suski A., Chrzest według Didachè, w: K. Konecki (red.), Laudate Dominum. Księdzu profesorowi Jerzemu Stefańskiemu z okazji 65-lecia urodzin i 40-lecia kapłaństwa, Gniezno 2005, s. 287-306.

Suski A. (oprac.), Rękopiśmienne mszały przedtrydenckie. Katalog sumaryczny, Toruń 2017 (=Fontes Scrutari, t. 2).

Suski A. (oprac.), Sakramentarze. Przewodnik po rękopisach, Toruń 2016 (=Fontes Scrutari, t. 1).

Suski A.W., Baroffio G., Sodi A., Rotoli liturgici medievali (secoli VII-XV). Censimento e bibliografia, „Rivista Liturgica” 101 (2014) 3, s. 603-621. 
Torti Mazzi R., La preghiera ebraica. Alle radici delleucologia cristiana, Cinisello Balsamo 2004.

Valli N., I lezionari al tempo dei sacramentari Veronese, Gelasiano e Gregoriano, „Rivista Liturgica" 101(2014) n. 3, s. 501-521.

Zachara M., Krótka historia mszału rzymskiego, Warszawa 2014. 